\title{
SZÜLETŐ VÁROS: KÁPOSZTÁSMEGYER
}

\author{
(The springing town: Káposztásmegyer) \\ RIGÓCZKY CSABA
}

Az alábbiakban Budapest egy különleges városrészét az Újpesthez (IV. kerület) tartozó Káposztásmegyert szeretném bemutatni. A káposztásmegyeri lakótelep igen figyelemre méltó, több szempontból is egyedinek mondható.

1. 1980-as évek elején kezdődött meg az építkezés, mikorra már nyilvánosságot kaptak a lakótelepekkel szembeni lakossági ellenérzések, az építészek véleménye pedig megoszlott, egy részuik a telepszerú épitkezés beszüntetése, más részük annak megreformálása mellett tört lándzsát.

2. A kőzlekedési infrastruktúra és a kereskedelmi infrastruktúra messze az igények alatt marad. Ez utóbbi sajátos piaci folyamatokhoz, a kisvállalkozások kủlönleges szerepéhez vezetett.

3. Káposztásmegyer területileg, közlekedés-földrajzilag és funkcionálisan is elszigetelt. Nem káposztásmegyeiek csak nagyon ritkán keverednek a városrészbe, Így az zártabb, kompaktabb egységnek tünik.

4. Mivel a városrész 10 év körülinek mondható, kis túlzással azt állíthatjuk, hogy egyidős a rendszerváltással. Ez nemcsak gazdasági de politikai értelemben is érdekes jelenségeket takar.

5. A lakótelepeken a fiatalok aránya átlag felettinek mondható. Ez különösen igaz a Káposztásmegyeri lakótelepre.

6. A közelmúltban fogadták el a városrész részletes rendezési tervét, mellyel az 1990es évek legnagyobb építkezése veszi kezdetét.

1. Az 1980-as évek elejére széleskörủ társadalmi elégedetlenség kapott hangot, a lakótelepekkel kapcsolatban, és a különböző szakterületek múvelői is határozottan a lakótelep építés hátrányaira világítottak rá. Perényi Imre, a magas állami kitüntetésben részesült építész 1983-ban erős hangvételben támadta a lakótelep-építés koncepcióját, és azt állította, hogy "kétségkívül városaink lakótelepszerü fejlesztést eredményezỏ extenzív szakasza lezárult." Szirmai Viktória Csinált vărosok címủ könyvében Le Courbusier-ig visszamenỏleg vizsgálja a semmiből épített városokat, és álláspontja nem nagyon optimista. Rávilágít arra is, hogy a lakótelepi lakások kis alapterületének oka eredendően az a korábbi elképzelés, hogy a napi funkciók (pl. étkezés) mind nagyobb hányada fog a közös helységekben történni, az épületek túlzott sủrủsége pedig az új és újabb takarékossági intézkedéseknek köszönhető.

Az 1980-as népszámlálás 35. kötetének tanulsága szerint a fóváros népességének $35,4 \%$ a élt lakótelepen (552351 lakos). Tizenkét lakótelep népessége haladta meg a 10000 föt, közüluak pedig három 30000-nél is nagyobb volt (Óbuda: 47442, Füredi út: 34978, Újpalota: 57042). Vidéki városainkban tizenöt lakótelep volt népesebb 10000 fönél, de a többi, abszolút népességszámban kisebb egységet sem szabad figyelmen kívül hagyni, 
mert arányuk a város lakosságához képest ugyancsak jelentős. Országos átlagban a városi lakosság lakótelepeken éló aránya a budapestit is meghaladó $40,3 \%$ volt.

A magyar lakótelepek története összecseng a bécsi városbövítési és város-felújitási ciklusok modelljével. Az elmélet szerint egy város fejlődésében az új városrészeket (esetünkben lakótelepeket) épitö növekedési, és a régi városrészeket regeneráló felújitási szakaszok váltogatják egymást. A ciklus innovációs, fellendülési, fö- és késői szakaszból áll. Az első szerény méretủ lakótelepek az 1950-es években épültek, majd az 1960-70-es években vált tömegessé az építkezés (a kelenfơldi lakótelep elöközmüvesítési munkálatai 1964-ben kezdódtek, a zuglói 1968-ban az Óbudai 1968 után kezdett épülni). Akkoriban nagy eredménynek számított, hogy polgárok tömegei jutottak összkomfortos lakáshoz, és a változások mértéke akkora volt, hogy többhelyütt "modern honfoglalásról" beszéltek. Az 1980-as évek elejére csökkentek az építkezésèk, Budapest elért a városnövekedési szakasz késỏi fázisába, és a lakótelep építés helyett az addig elhanyagolt belvárosi felújításokra, és a foghijjak beépítésére került a sor. A társadalmi elégedetlenség föbb okai közt említhető a túlzott laksürüség, a kicsi lakás- és helységméretek, a házgyári monotónia, az intézményi hiányosság, és a zöldterületek hiánya. Az említett újpalotai lakótelepen pl. az intézményi terület $4,2 \mathrm{~m}^{2} / \mathrm{fö}$, ellentétben a $11,4 \mathrm{~m}^{2}$-es igénnyel. A zöldfelület $10,25 \mathrm{~m}^{2} / \mathrm{fö} \mathrm{a} 14 \mathrm{~m}^{2}$-rel szemben, és annak is nagy része autóparkolóként funkcionál.

Miként illeszkedik Káposztásmegyer a képbe? Ez a városrész az ismertetett ciklusnak a végsỏ fázisában afféle "utolsó mohikánként" kezdett épülni. Az 1970-es években népességét 70000 (!) före tervezték, nagyobb lett volna, mint megyeszékhelyeink jelentős része. Németh Károly, vezetö politikus egy beszédében azt mondta, "Ott, azon a Káposztásmegyeren nem lakótelep épül, hanem egy új városrész. (..) A Központi Bizottság világosan szólt arról is, hogy a kor színvonalán, minden igényt kielégitő városnegyed fog megépülni." A jóslat nem teljesedett be. A lakótelepi építkezések megakadtak. Ma Káposztásmegyer népessége kb. 27450 fö (pontos adatokkal még az önkormányzat sem rendelkezik). Az ellátóintézmények hiánya jelentős. Az eredeti tervek két építési ütemmel számoltak: Az elsô ütem 5749 lakása kb. 20700 lakos számára a tervek szerint el is készült. Ebben a részben körülbelül egyenlö arányban találhatók a 10 emelet magas, és a három-négy emeletes középmagas házak (2879:2820). Ez utóbbiakról elmondhatjuk, - amit kevés más magyar lakótelepi házról - hogy szépek. A tervezók többfunkciós házakat terveztek, ahol a földszinti részen kirakatokat, üzleteket, presszókat, mủhelyeket lehet kialakitani. Formailag és funkcionálisan is visszahozták a korábban számủzött utca-élményt, a tagolt homlokzatot, és a "sátortetőt". A házak elé előkerteket a befelé nézỏ oldalak közé pedig afféle belső udvarokat terveztek, igy olyan terek alakultak ki, ahova idegenek nemigen járnak, és melyet a lakók sajátjuknak érezhetnek. Berényi András - Újpest, és így Káposztásmegyer foépitésze - helyesen látja, hogy az emberek olyan lakásra vágynak, amelyben a városi élet elónyei aż intim kert közelségével szintetizálódnak. Egy 1987-ben megjelent írásában arra hívja fel a figyelmet, hogy ugrásszerúen nött a hagyományos családi házas telkek iránti kereslet, mégis "Nagy hiba lenne további területi terjeszkedéssel (termőföldek feláldozásával) kertvárosként tervezni a fejlödést (...) a hetvenes évek tömeges lakásépítését elfelejteni, azt teljesen abbahagyni (...) nem lenne helyes." A kertvárosok iránti igény nem magyar sajátosság, ez az Enyedi György által relatív dekoncentrációnak nevezett folyamat évtizedekkel ezelött megkezdődött az USA, és Nyugat-Európa fejlett országainak nagyvárosaiban. A később ismertetésre kerüló felmérés szerint Káposztásmegyer gimnáziumában a 17-18 éves káposztásmegyeriek közül mindössze ketten szeretnének lakótelepen lakni, az összes többi 
Tér és Társadalom 10. évf. 1996/2-3. 31-41. p.

fiatal kertvárosban képzeli el a jövőjét. Mindez nem mond ellent annak, hogy a megkérdezettek kétharmada elégedett a városrésszel.

A második ütem építkezései nem fejezödtek be. Az eredeti tervben itt is egyenlö lett volna a magas és a középmagas épületek aránya, azonban a befejezetlenség és az utólagos módosítgatás miatt, 1:3 arányról beszélhetünk (1389:485). Az eredeti tervek a betelepülő lakosság tekintetében is változtak. Eredetileg öröklakásokat terveztek, és kevés gyermekkel számoltak, később mégis nagycsaládosok kapták meg a lakásokat tanácsi bérlakásként. Ennek számos következménye közül egyik az iskolahiány. Évekig húsz osztályt kellett buszoztatni, mert nem volt elég iskola. A második ütem része lett volna a városközpont is, minek hiánya messzire nyúló következményekkel járt. Ezen a területen pl. nincs orvosi rendelö. A félig kész lakótelep-korzót, az ellátó intézmények hiánya és a városkép foghíjjai jellemzik.

2. A kereskedelmi ellátás koncentrációja igen alacsony. Nagyobb élelmiszerbolt csak kettö van, azok is szó szerint egymás szomszédságában, a városrész peremén. (Van még két $\mathrm{ABC}$ üzlet, de azok is csak kis alapterületüek.) Hiányoznak a javitó, szolgáltató intézmények, virág- és könyvesboltok és ruházati áruház is.

\section{TÁBLÁZAT}

A kereskedelmi és vendéglátó intézmények tervezett és meglévö területnagysága (The trade and catering institutes - planned and realised)

\begin{tabular}{|l|c|c|c|c|c|c|}
\hline \multirow{2}{*}{} & \multicolumn{3}{|c|}{ kereskedelem } & \multicolumn{3}{c|}{ vendéglátás } \\
\cline { 2 - 7 } & I. ütem & $\begin{array}{c}\text { II. } \\
\text { ütem }\end{array}$ & összesen & I. ütem & II. ütem & összesen \\
\hline meglévỏ állapot $\left(\mathrm{m}^{2}\right)$ & 12100 & 1800 & 14000 & 14000 & 450 & 1850 \\
\hline lakosságszámra vetített normatív szúkséglet $\left(\mathrm{m}^{2}\right)$ & 14000 & 4050 & 17050 & 7250 & 2350 & 8200 \\
\hline normatívák szerinti ellátottság $(\%)$ & & & & 19 & 19 & 22 \\
\hline normativ hiány a tervezett állapotra $\left(\mathrm{m}^{2}\right)$ & 300 & 2850 & 3050 & & & \\
\hline
\end{tabular}

Forrás: Urbanitás Kft.

A kialakult hiányt a lakótelepi házak földszinti részeiben múködő kisboltok pótolják. Ezek az üzletek már csak méretüknél fogvia is nagyon rugalmasak, és maximálisan piacorientáltak. Gyakorta változik egy-egy üzlet kínálata különbözỏ, látszólag össze nem illỏ termékek kapnak egymás mellett helyet, és a boltok teljes profilváltása sem ritka. Sokuk esetében pl. teljesen más a kirakat feletti felirat, mint a bolt profilja, ami a közelmúltban történt váltást, a helyezkedést tükrözi. A kisboltok egymással igen éles versenyben állnak, viszonyuk a klasszikus közgazdaságtanban leírt szabad versenyre emlékeztet. Nyár elején diákjaim segítségével felmértük Káposztásmegyer I. összes üzlethelységét. A felmérés eredménye: Káposztásmegyer I. lakótelepen a "mini market"ek voltak a legnagyobb számban (46). Nagy számuk már lehetővé teszi a legközelebbi szomszéd analízis elvégzését. Az előzetes számítás nagyfokú, de mégsem 100\%-os szórtságot sejtet, azt a logikus eredményt mutatja, hogy a nagyboltok mellett ezek a "mini marketek" nem találhatók meg, ugyanakkor a sokemeletes házak "tövében" több, az alacsonyabbaknál kevesebb van belölük. Eloszlásukban tehát a piac igényei (a vásárlók száma) határozottan tükröződik. Az élelmiszerboltok mögött második helyen a ruházati boltok száma áll (24), melyek között a használt árukat kínáló "kilós boltoknak" körülbelül 
ugyanakkora az aránya, mint az új divattermékeket áruló butikoké. A javitómühely kategória (19) igen összetettnek tekinthetö (a ruházati, böripari, elektrotechnikai stb. szolgáltatást végző vállalkozások valamennyien ide kerültek besorolásra). A presszókkocsmák száma - többek meglepetésére, és egyesek bánatára - csak a negyedik helyen áll (17). Étterem (nem gyorsbüfé) csak egy van a lakótelepen, az is külön "kocsmahelységgel". Érdekes, hogy csak egyetlen eggyel van kevesebb (16) a "szépségszalonokból".

\section{TÁBLÁZAT}

Káposztásmegyer I. lakỏtelep szolgảltató intézményeinek száma (db) (Service units in Káposztásmegyer I. housing estate)

\begin{tabular}{|l|c|}
\hline "mini market" & 46 \\
\hline ruhabolt & 24 \\
\hline javító mühely & 19 \\
\hline presszó-kocsma & 17 \\
\hline szépségszalon & 16 \\
\hline játék - szuvenír & 7 \\
\hline videotéka & 6 \\
\hline papírbolt & 6 \\
\hline újságos & 4 \\
\hline díszhal kereskedés & 4 \\
\hline virágbolt & 3 \\
\hline fényképész & 3 \\
\hline gyógyszertár & 3 \\
\hline cukrászda & 3 \\
\hline posta-bank-biztosító & 3 \\
\hline háztartási bolt & 2 \\
\hline híradástechnikai szaküzlet & 2 \\
\hline autósbolt & 2 \\
\hline játékterem & 2 \\
\hline kónyvesbolt & 1 \\
\hline cgyéb & 4 \\
\hline
\end{tabular}

Forrás: TZSU, 1995.

Akik sok éve ismerik a városrészt megfigyelhették, hogy a boltok mai aránya folyamatosan alakult ki, ugyanabban a helységben 3-4 különböző típus is váltotta egymást. A folyamatot szigorúan a piac vezérelte. Mára egyfajta rugalmasság alakult ki, de a vállalkozók rugalmassága még mindig nagy, így a fent vázolt kép pillanatfelvételnek tekinthető. A lakótelepen piac egyáltalán nincs, helyette szombatonként egy spontánul kialakult, ázsiai állapotokat idézô, illegális, de megtürt "lengyel piac" mükődik, ahol teherautó platóról árulják a húst, a tejterméket, a pékárut, a bort, a zöldséget, a háztartási cikkeket.

A helyi lakosság egyébként elégedetlen a kialakult helyzettel, föképp a "mini marketek" tekintetében, mert a kisboltokban a kínálat alacsonyabb, az árak viszont magasabbak, mint ha élelmiszer-áruházakban vásárolhatnának. Egy érdekességre azonban hadd hívjam fel a figyelmet: szinte minden lakótelepi háznak megvan a maga vegyesboltja, és a sok kisbolt a törzsvásárlókkal emberközeli, kisvárosi hangulatot teremt. Mindenki ismer mindenkit, és 
egyfajta közösségi élet formálódott a boltok falai között. Többek között ezzel is magyarázható, hogy a helyiek közmondásszerüen emlegetik: „Káposztás' olyan, mint egy nagy falu".

3. A városrész területileg, közlekedés-földrajzilag és funkcionálisan is elszigeteltnek mondható. Területi szempontból minden irányból széles, gazos, járhatatlan pusztaság határolja. Dél felöl a metrónak fenntartott sáv, a mögött a Vác-Budapest vasútvonal választja el Rákospalota kertvárosától. A vasúton egyetlen átjáró van, azon sem halad tömegközlekedési eszköz, és föútvonalat találni csak hosszú séta után lehet. Kelet felé szintén széles beépítetlen sáv, majd a Szilas-patak (mindössze két híddal), annak túloldalán pedig Újpest kertvárosi része következik. Keletről a városhatár, északról pedig egy erdősáv, pusztaság, a 2-es föút és a Duna határolja.

A közlekedési elszigeteltség jelentős. Az építkezés kezdetén azt tervezték és ígérték, hogy a metró végighalad a lakótelepen, ez a terv azonban nem valósult meg. Már 1983 tavaszán nyilvánvaló volt, hogy a metró késve épül meg, és a szkeptikusok azt állították, hogy átadása az ezredforduló elött nem is várható. A metrónak fenntartott terület (a végállomás, a remiz, a szerelöcsarnok területét is beleértve) ma beépítetlen, poros, gazos üresség. Ezen az önkormányzat által hozzáférhetetlen területen müködik a már említert illegális "lengyel piac". Metró helyett az annak kijelölt, és részben kiépített vonalon a 14 jelü villamos közlekedik, és köti össze a városrészt Újpest - Központ végállomással, ám ez a villamosjárat is csak a lakótelep pereméig halad. Ezen kívül egyetlen autóbuszjárat a piros húszas köti össze Káposztásmegyert a Keleti pályaudvarral, ám ez is elkerüli a fontos közlekedési csomópontokat, és igen lassú. A lakótelepen belül két körjárat a 124-es, és a 126-os kanyarog afféle füzfaexpesszként. Mindez a gyakorlatban azt jelenti, hogy menetidóben számítva a városrész messzebb van a Deák-tértöl, mint Budakalász. A menetrendek olyanok, hogy annak aki 11 óra után érkezik haza, és nem akar taxira költeni $2-2,5 \mathrm{~km}$ gyaloglásra is vállalkoznia kell. (A villamosvonal meghosszabbitásával remélhetőleg ez a probléma egy éven belül enyhülni fog.)

Funkcionális értelemben a lakótelepnek nincsenek a telepen túlmutató vonzerövel bíró intézményei, pl. áruházai, közép- vagy nagyvállalatai. Két középfokú intézménye a gimnázium és a kultúrház is a városrész szélén kaptak helyet. A lakótelepnek tehát átmenỏ forgalma nincs, és bejárókkal is ritkán találkozhatunk.

4. Az 1989-es fordulat óta a városoknak és a falvaknak is megnőtt a mozgástere. Az önkormányzatok, és a civil szervezetek izmosodása az identitástudat, és az oly sokszor emlegetett egészséges lokálpatriotizmus megerösödéséhez vezetett. A lakótelepeken általában gyenge a lakhellyel való azonosulás, Káposztásmegyeren azonban a zártság, az emberléptékủ házak nagyobb aránya, és a vegyesboltoknál említett intim miliö ellensúlyozza a negatív anomáliát. Az identitástudat erősödését szolgálja az is, hogy a lakások többségét a lakók megvásárolták. Azóta igen érdekes jelenségnek lehetünk tanúi. A lakók egyre több helyen gondozásukba veszik a lépcsőházakat, a lifteket, a házak elötti kis előkerteket, erélyesen fellépnek a falfirkáló, rongáló gyerekekkel szemben, és szemmel láthatóan jobban vigyáznak a házra, mint máskor. A civil szféra erősödését jelzi, hogy saját részönkormányzat alakult. A részönkormányzat deklaráltan az Újpesti Önkormányzat alatt k0ván dolgozni és valóban ez tünik az egyetlen racionális lehetőségnek mégis sokan úgy vélik, hogy a városrész elöbb-utóbb elszakad a IV. kerülettől. 1996 nyarán alakult meg a "Káposztásmegyerért egyesület", amely az összetartozást hivatott erösiteni. Az alapítók célja, hogy a káposztásmegyeriek pártállástól függetlenül fogjanak össze. Újpest 
fóépítésze szerint: "Rajtunk - a város polgárain (legyünk bármilyen "csapat mezében") - és senki máson nem múlik, hogy az adott lehetőségen belül lépéseinket milyen irányba tesszúk. Nem várhatjuk, hogy városunk szebb, otthonosabb, emberszabásúbb, tisztább, barátságosabb legyen, nekünk kell azzá tenni. (...) (Bocsáss meg nekem Madách mester): a gép nem forog, ha az alkotó pihen."

5. A lakótelepeken a fiatalok az országos átlagnál jóval nagyobb arányban reprezentáltak. Káposztásmegyer népessége is jóval fiatalabb az átlagosnál. A 19 évnél fiatalabbak aránya $49 \%$ szemben a $24 \%$-os budapesti átlaggal. (A fỏiskolai/egyetemi végzettség $23 \%$, a fóvárosi 10,6\%-kal szemben) A relatív fiatalság az elörejelzések szerint még évtizedekig megmarad, sőt a kerület vezetői a fiatalok magas arányának "visszatérô hullámzásával" számolnak. Ezen visszatérỏ hullámra viszont csak akkor lehet számítani, ha a szülöképes korú nók nem költöznek el, tágabb értelemben, ha a fiatalok sajátjuknak érzik a városrészt. Egy kérdőíves felmérés keretében Egedy Tamással azt vizsgáltuk meg, hogy a fiataloknak milyenek a városrésszel szembeni érzelmeik, és miket tartanak a legsúlyosabb városi gondoknak.

A felmérést a Babits Mihály Gimnázium (BMG) 3., 4. osztályosai körében végeztünk el. (Az összes 17-18 éves gimnazistát megkérdeztük, de az alábbiakban csak a Káposztásmegyeri lakosok válaszait mutatjuk be.) A válaszolók száma nem meríti ki a statisztikai sokaság fogalmát, és a gimnazisták sem tekinthetók az egész Káposztásmegyert reprezentáló mintának, ugyanakkor a mintavétel jól reprezentálja a felnőttkor kủszöbén álló, a jövőben valószínủleg felsöfokú végzettséget szerző csoportot, kiket jó lenne a városrésznek megtartani (A BMG felvételi aránya 62\%). A jövőben tervezzủk tágítani a vizsgált személyek körét.

Az elsố kérdéscsoport egy polaritás-profil elkészítésére vonatkozott. -2 és +2 között (tehát egy ötfokú skálán) kellett jelölni, hogy ellentétes tulajdonságokra nézve milyennek ítélik Káposztásmegyert. A kérdések a szubjektív véleményre vonatkoztak, mely érzelmeken múlik (pl. szép, gazdag, vidám). A válaszok végûl is Káposztásmegyer városimage-ére mutatnak rá a fiatalok szemszögéböl. Az eredmény határozottan optimista képet mutat. A tulajdonságok többségét pozitívnak találták, a kérdések majd fele a 0,4-es érték felé kúszik, a stabilitás és a rugalmasság pedig a nagyon magas, 1-es értéket is meghaladja. Említésre méltó negatív értéket az unalmasság, jellegtelenség (izgalmas ellentéteként), és a zárkózottság vett fel (1. ábra).

A második kérdéscsoportban a városi problémákat kellett pontozni a gyerekeknek I-tôl 10-ig, a jelenre és a jövöre vonatkoztatva. Jelen idóben az egészségtelen életmódot, azon belül az alkoholizálást és a dohányzást, illetve a környezetszennyezést, a parkok hiányát érzik legnagyobb gondnak. A "második vonalban" nagyon kicsi a különbség. A szegénységet, a munkanélküliséget, a rossz közbiztonságot, a családok széthullását a fiatalok még nem érzik olyan súlyos gondnak, mint a felnőttek. Az elvándorlás, a más városokkal való összeköttetés és a helyi közlekedés 3-as, illetve alacsonyabb értéket vett fel és ez nagyon jó eredmény. A szórakozási és a kulturális lehetỏségre vonatkozó két kérdés is alig haladja meg a 3-as értéket. (Ez utóbbi látszólag ellentmond az elözỏ feladatban az "unalmasságról" mondott véleménynek, a valóságban azonban a "nem gond a közlekedés" érzéssel magyarázható.) A közlekedés kérdésköre különben is érdekes, hiszen a felnőtteknek ez az egyik legsúlyosabb problémája (2. ábra). 


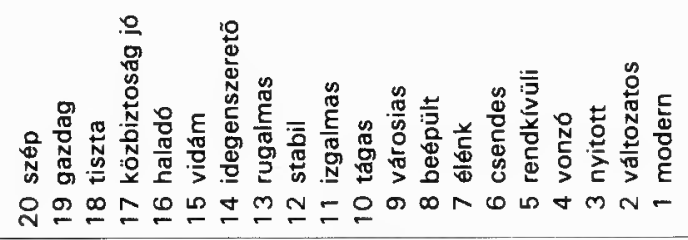

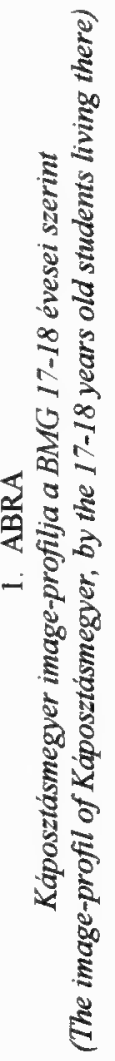
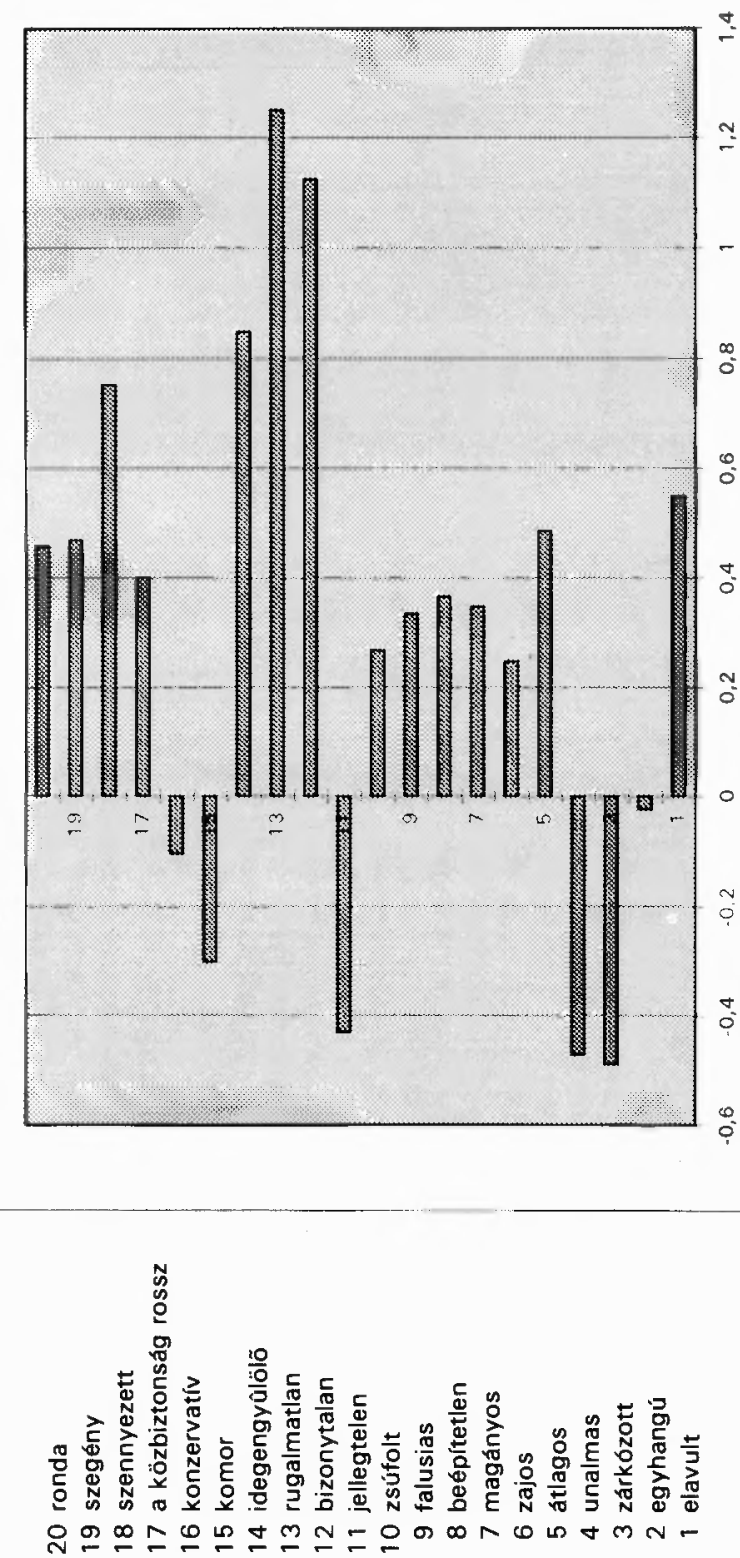

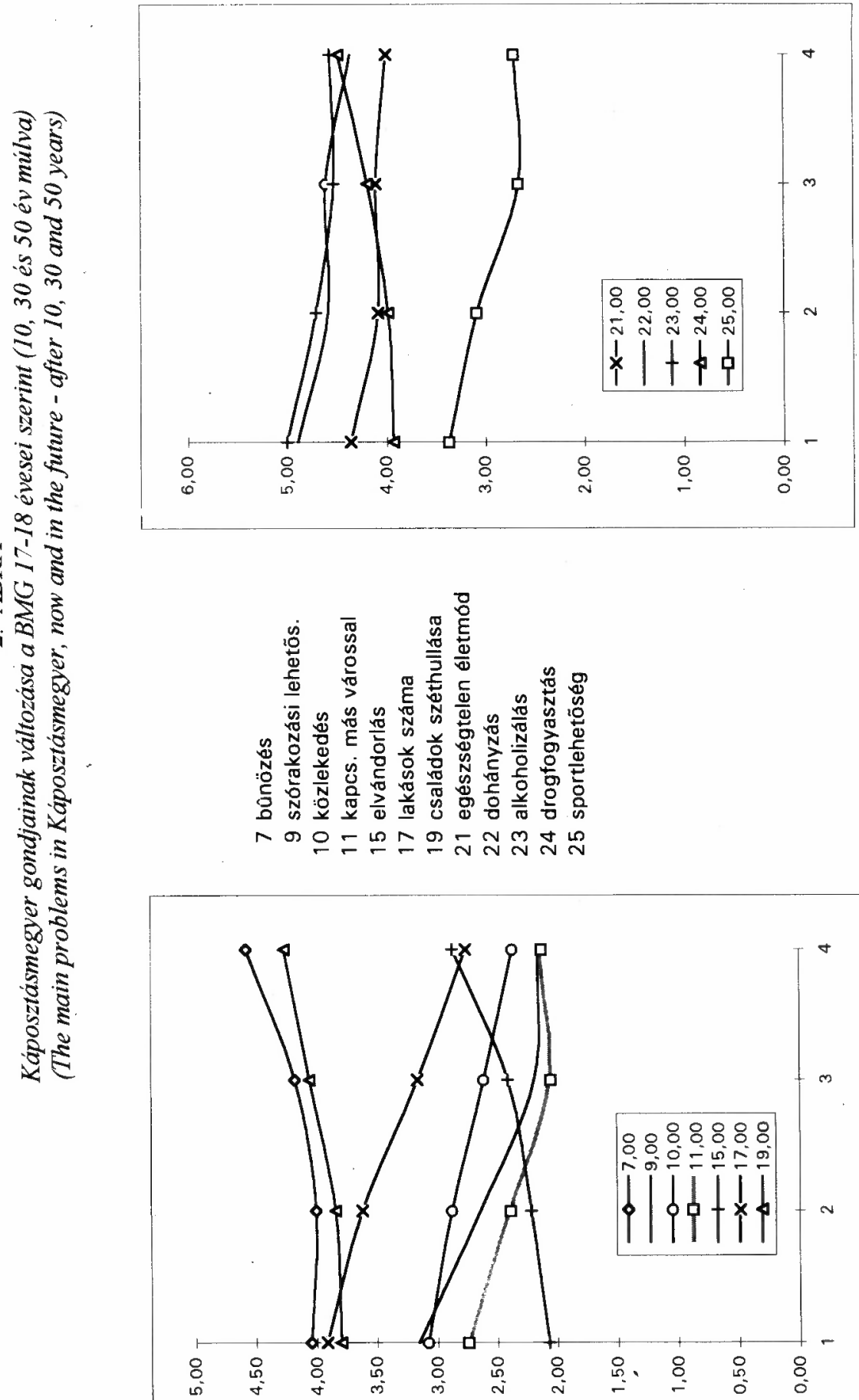
A városi problémák jövőbeni alakulására vonatkozóan a gyerekek nem számítanak nagy változásokra. Említésre méltó változást csak néhány esetben tapasztaltunk. Föképp az infrastrukturális kérdésekben várnak javulást, úgy gondolják az életmód is javulni fog, ugyanakkor a drogfogyasztás, a bünözés erősödését jósolják, valamint, az elvándorlás problémaköre is elmozdul a mostani szerintük nagyon alacsony szintröl (3. ábra). A kérdéssorra a 13-14 évesek is válaszoltak, ezek elemzése azonban meghaladja a jelenlegi keretünket.

6. Káposztásmegyer fejlődésére tehát szó szerint igaz a megállapítás, hogy a városrész "kicsit félbemaradottnak hat. (...), tehát az évtizedek múlva újra visszatéró ciklus jószerivel a régiben abbamaradt munkák folytatásával kezdődhet." ${ }^{7}$ Valóban ủjrakezdődnek az építkezések. Idén került elfogadásra Káposztásmegyer részletes rendezési terve, annak reményében, hogy az évtized egyik legnagyobb városépítészeti vállalkozása veszi kezdetét.

A részletes tervből, most csak néhány jelentősebb elemet emelünk ki. Káposztásmegyeren egy forradalmian újszerü beruházás veszi kezdetét. A tervek mérete és sokoldalúsága oda mutat, hogy Káposztásmegyer - amely már most is határozottan elkülönülő ökológiai egység - egy. sokfunkciós városrész lesz - város a városban. A korábbi tervekkel ellentétben "kertváros" és "vállalkozói negyed" épül. A vállalkozói negyed nevủ részben három zóna különül el: legtávolabb a kettes foút mentén a zajos, sok alkalmazottat foglalkoztató 1-2 ha-os üzemek kaphatnak helyet, a teherautó- és kamionforgalom szigorú szabályozása mellett. A második zónába a középvállalkozások települhetnek 3000-4000 $\mathrm{m}^{2}$-es telkekre, a legbelső, harmadik zóna pedig az 1200-1500 $\mathrm{m}^{2}$-es családi kisvállalkozásoké, melyeknek környezeti és épitészeti szempontból szigorú feltételeknek kell megfelelniük. Teherautóforgalmat sem vonzhatnak, szigorúan meghatározott a mủhely, a garázs és a lakások helye, mérete, homlokzata. Ezen városrész 13,75 ha területen remélhetöleg a funkcionális gyarapodás, és a munkahelyteremtés mellett bevételekhez is juttatja az önkormányzatot. A vállalkozói negyed ingatlanjai bizonyára nagyon értékesek lesznek, és kedvezó eséllyel, jól menỏ vảllalkozásoknak adnak majd teret, (a városrész határában fog futni az M0-ás körgyürủ). Az autópálya-építést sokan ellenezték, mert környezeti ártalomtól tartanak, ugyanakkor nem szabad elfelejteni, hogy gazdasági szempontból a városrészre nagyon is kedvezỏ hatással lehet. Határozat született arról is, hogy a terület értékesítéséből befolyó bevételek Káposztásmegyer közintézményeinek építésére fordítódjanak (áruház, sportpálya, templom). Az üzleti érdekek érvényesítésére a fỏvárosi és a kerületi önkormányzat "zászlaja alatt" a napokban részvénytársaság alakult (Észak-pesti Ingatlan- és Térségfejlesztési Rt).

A kertváros nevủ terület 47,7 ha területére maximum háromszintes saját lakókerttel rendelkezó épületek épülnek. $1778 \mathrm{db}$ az átlagosnál értékesebb lakást terveznek. Építészeti, környezeti, és városképi szempontból ugyancsak rendkívül részletesek a tervek. A szigorú tervezés ugyanakkor a tervezhetőség elméleti kérdéseit is felveti. Mennyit ér a terv? Erre a kérdésre a fóépítész a már említett cikkben megadta válaszát: " Egy terv önmagában nem vállalkozhat arra, hogy feszültségeket oldjon fel, gondokat orvosoljon, arra viszont igen, hogy tanácsokat, útmutatásokat adjon mindazoknak a szakembereknek, kiknek kötelessége, és felelősége a gyógyító beavatkozás." 8 


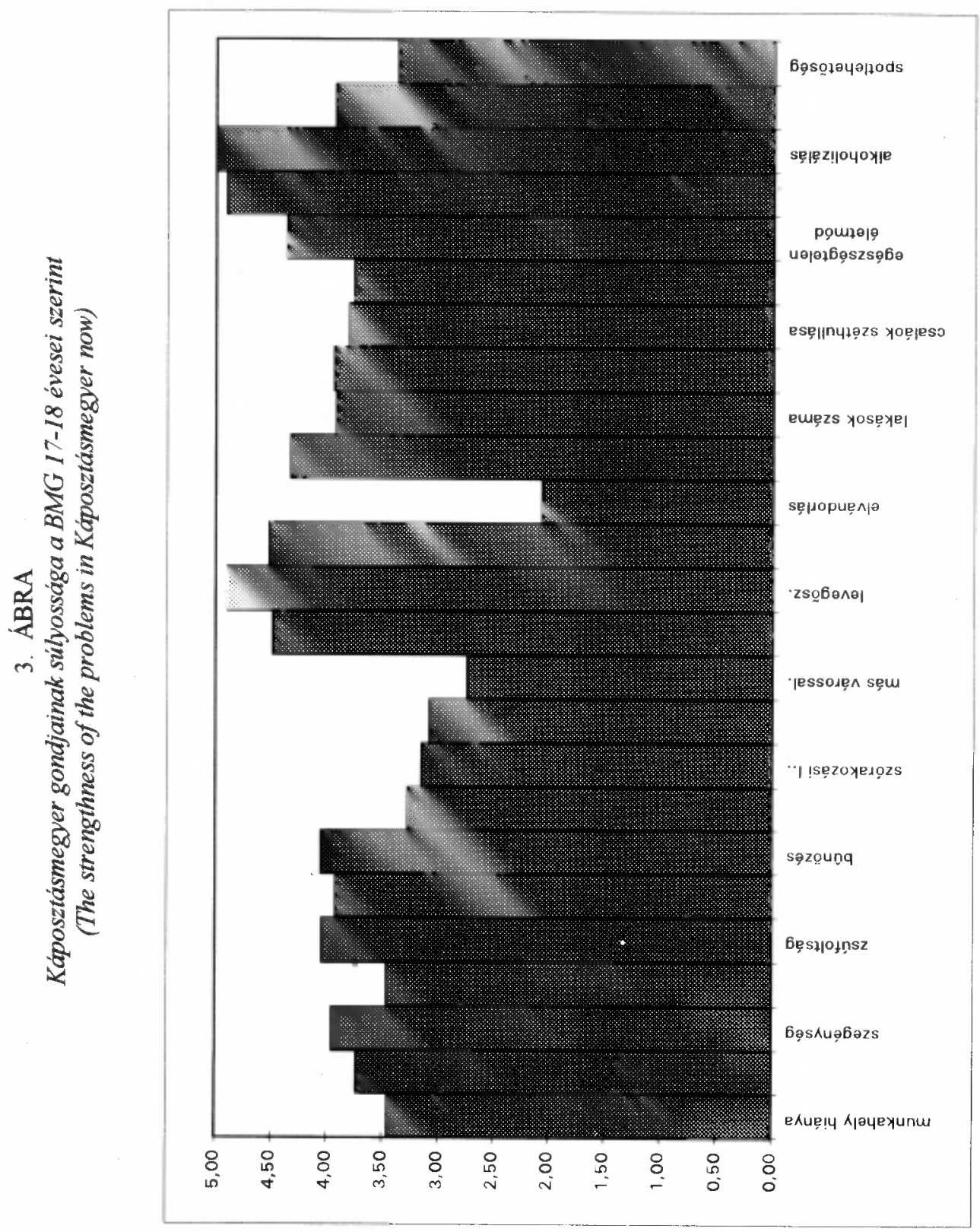


A tervek csak kereteket adnak, megmutatják miként fokozható a regionális potenciál, de Káposztásmegyer jövője attól függ, hogy a kerület vezetői miként gazdálkodnak a meglévő belső (endogén) erőforrásokkal, és miként fejlesztik a ma még hiányzókat. Rechnitzer János rendszerezése alapján "az alábbi tényezöcsoportokhoz köthetök az endogén források, mint a regionális potenciál meghatározói:

- tỏkepotenciál (rendelkezésre álló termelöbázisok és vagyon),

- munkaeró adottsága, iskolázottsága, képzettsége,

- infrastruktúra felszereltsége,

- földrajzi helyzet,

- környezeti állapot és minőség,

- piaci kapcsolatok (keresleti tényezők),

- szocio-kulturális adottságok,

- döntési, intézményi és hatalmi rendszer.

(...) ezen endogén tényezök (...) bizonyos társadalmi, gazdasági körülmények között megindíthatnak aktivizációs folyamatokat, kiválthatják, vagy magukban hordozhatják az adott régió megújitásának lehetőségét." Mint az eddigiekből kiderült a városrész ma még csak néhány erőforrás terén jelentős, a következö évtizedek azonban Budapest egyik legdinamikusabb városrészévé tehetik Káposztásmegyert.

\section{Irodalom}

Gséfalvay Z. (1994) A modern társadalomföldrajz kézikönyve. Ikva Kiadó, Budapest. 366. o.

Enyedi GY. (1988) A városnövekedés szakaszai. Akadémiai Kiadó, Budapest. 124. o.

In város születik (film)

Perényi I. (1983) Lakótelep-épités vagy komplex városfejlesztés. In Városépités 2.sz.

Rechnitzer J. (1993) Szétszakadás vagy felzårkózás. MTA RKK, Györ. 208. 0.

Szirmai V. (1988) Csinált városok. Gyorsuló Idő Sorozat, Magvető Kiadó, Budapest. 240. o.

Városok évkőnyve.(1987) Magyar Urbanisztikai Társaság,

\section{Abstract}

Nowadays Káposztásmegyer is a part of the Hungarian capital, struggling with a lot of problems, but achieving some advantages, too. It's position is positive looking at the people, the local society (e.g. age-structure), or it's achitectural profile, but negative if we see the infrastructural level, the isolation from the inner part of the capital. The improvemens in the near future may result a sudden development, some other people wait stagnation, the third opinion says that great mass of environmental pollution will come. The truth is: Káposztásmegyer is the city of the fututre, if we see the things on an optimistic way, or the pessimistic. 